\title{
RST 課題遂行中の眼球運動の計測
}

\author{
○東美由紀 ${ }^{1} \cdot$ 源健宏 $^{1} \cdot$ 苧阪満里子 ${ }^{1} \cdot$ 苧阪直行 $^{2}$ \\ ( ${ }^{1}$ 大阪大学大学院人間科学研究科 $\cdot{ }^{2}$ 京都大学大学院文学研究科) \\ キーワード : ワーキングメモリ，リーディングスパンテスト，眼球運動
}

Measurement of the eye movements while performing Reading Span Test

Miyuki AZUMA ${ }^{1}$, Takehiro MINAMOTO ${ }^{1}$, Mariko OSAKA ${ }^{1}$ and Naoyuki OSAKA ${ }^{2}$

$\left({ }^{1}\right.$ Graduate School of Human Sciences, Osaka Univ., ${ }^{2}$ Graduate School of Letters, Kyoto Univ.)

Key Words: working memory, reading span test, eye movement

\section{目 的}

ワーキングメモリ（WM）は, 高次認知活動に必要な過程 である情報の一時的な保持と処理を注意制御のもとで支え, 最終的な目標へと導くシステムである（Baddeley, 2007）。WM の個人差を測定するリーディングスパンテスト（RST）は， WM の注意制御能力を反映していると考えられる。 RST の低 得点者は，一旦注意を向けた対象を抑制することが困難であ るということが示されている（苧阪，2002）が，RST 遂行中 の眼球運動を測定することで, WM の注意制御能力を検討し た研究は少なく, そのどれもが英語もしくは英語と類似した 文法体系を持つ言語で実施されていた。また, これらの研究 の結果は一致していない。本研究では, 日本語版 RST 遂行中 の眼球運動を計測することで, WM の注意制御能力を検討し た。先行研究との相違点は, 日本語文法の特徵から, RSTに おいて保持すべき単語の位置が文内で固定されていないこと である。このことは注意制御をより要求すると考えられ, 先 行研究よりも WM の注意制御能力の差が顕著に反映されると 推測される。

\section{実験参加者}

\section{方 法}

大阪大学の学部生・大学院生 51 名 (年齢 19-32 歳) のうち, 眼球運動のデータが正確に計測できた 30 名を分析対象とし た。眼球運動の計測に先立ち，標準版 RST（苧阪， 2002）を 実施した。その課題成績を基に群分けをした結果, 高得点群 (スパン得点 3.5-5.0) が 14 名, 低得点群 (スパン得点 2.0-3.0) が 16 名となった。

\section{眼球運動計測・データ分析}

眼球運動の計測には, トビーテクノロジー社製の Tobii T120 アイトラッカーを使用した。取得したデータはトビーテクノ ロジー社製の Tobii Studio 2.2.8を用いて分析を行った。停留 の定義は, 半径 17 ピクセルの円内 (おおよそ 1 文字分に相当) に 50 ミリ秒以上の凝視がある場合とした。

\section{実験課題}

標準版 RST と同様の RST を行った。ただし標準版 RST と は異なり, 各文に先行して 500 ミリ秒の注視点が文頭の位置 に提示された。課題は読みの 2 条件 $(\mathrm{RST}$ 条件・READ 条件) と記憶負荷の 2 条件 (2 文条件・5 文条件) の計 4 条件を設け た。RST 条件では, 赤い下線の引かれた単語を保持し, 試行 の終わりに保持した単語を再生することが求められた。それ に対し READ 条件では, 赤い下線の引かれた単語を保持する 必要はなく, 試行の終わりに読み上げた文の数をカウントし た。記憶負荷の 2 条件は, 1 試行に含まれる文の数によって 操作した。2文条件は, 1 試行に含まれる文の数が 2 文となり, 記憶にかかる負荷が小さい。5 文条件は， 1 試行に含まれる文 の数が 5 文となり, 記憶にかかる負荷が大きい。これらそれ ぞれの条件について, 3 試行ずつ行った。

\section{RST 得点}

\section{結 果}

2 文条件（総単語数は 6 個）における総正再生数の平均值 は, 高得点群が 5.6 , 低得点群が 5.5 となり, 両者の成績には 違いが認められなかった $(F(1,28)=0.59, n s)$ 。これに対し， 5 文条件（総単語数は 15 個）における総正再生数の平均值は, 高得点群が 11.5 , 低得点群が 7.25 となり, 高得点群の成績は 低得点群よりも有意に高かった $(F(1,28)=18.46, p<.01)$ 。

\section{総停留時間}

各条件において，赤い下線の引かれた単語への総停留時間 を測定した。図 1 に群ごとの総停留時間の平均值を示す。

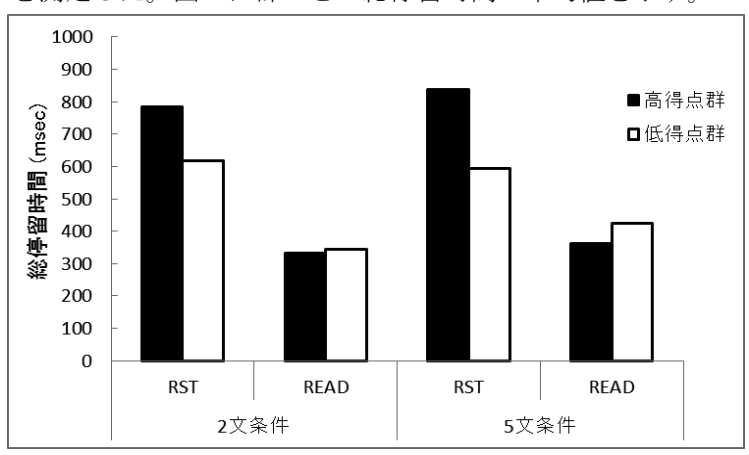

図 1. 赤い下線の引かれた単語に対する総停留時間

記憶負荷条件ごとに, 読み 2 条件 $\times$ 群 2 条件の 2 要因の分 散分析を行った。この結果, 記憶負荷 2 文条件では読みの主 効果のみが認められた $(F(1,28)=57.84, p<.001)$ 。れに対 し， 5 文条件では読みの主効果 $(F(1,28)=47.57, p<.001)$ お よび, 交互作用が認められた $(F(1,28)=10.71, p<.01)$ 。下位 検定の結果, 高得点群は低得点群よりも, 単語を保持する必 要がある RST 条件において, 記憶すべき単語に長い停留時間 を費やしていることが示された。

\section{考 察}

総停留時間の結果から, 単語を保持する必要のある RST 条 件において, WM 能力の高い人は, 記憶負荷が高く, より注 意制御が要求される状況下にも関わらず, 課題に必要な情報 に効率的に注意を向けていた。一方, WM 能力の低い人は, 記憶負荷が高い状況になると, 課題遂行に直接必要な情報以 外にも注意が分散しており, WM の注意制御の個人差の観点 からも更なる検討が必要と考える。

\section{引用文献}

Baddeley, A. (2007). Working Memory, Thought, and Action. USA: Oxford University Press.

苧阪満里子 (2002). 脳のメモ帳ワーキングメモリ 新曜社 